\title{
Undergraduate Course in Environmental Design and Manufacturing
}

\author{
Andrew S. Borchers, Dept. of Business; Trevor Harding and Terri Lynch-Caris, Dept. of Industrial and \\ Manufacturing Engineering; Benjamin Redekop, Dept. of Liberal Studies; Craig Hoff and Jackie El-Sayed, \\ Dept. of Mechanical Engineering; and Daryl Doyle (deceased), Dept. of Chemistry, Kettering University, \\ Flint, Michigan, USA
}

\begin{abstract}
This paper is a progress report on the development of an undergraduate course in environmental design and manufacturing. The importance of the topic is clear from National Academy of Engineering statements regarding the need to incorporate content on sustainable technology. The multidisciplinary team includes academic faculty from engineering, science, liberal studies, and business in collaboration with industry partners. The team's approach is to create a case-based course by adapting existing educational modules from Ford Motor Company. The group has received National Science Foundation funding for this project (DUE-0511322), and the project is currently in its beginning phases.
\end{abstract}

Koywords: Industrial Ecology, Sustainable Manufacturing

\section{Project Motivation}

According to the National Academy of Engineering, the growing environmental crisis means that, "Engineering practices must incorporate attention to sustainable technology, and engineers need to be educated to consider issues of sustainability in all aspects of design and manufacturing"(NAE 2004). This project will develop and employ proven, innovative pedagogical methods and tools to produce graduates able to incorporate environmental concerns into technical design and economic decisions. Currently, many universities like Kettering University do not offer meaningful instruction in this area, and what does exist tends to emphasize learning about air, water, and soil pollution rather than the environmental dimensions of manufacturing and product design (Powers et al. 2002).

This project is also a response to ABET (http:// $w w w . a b e t . o r g$ ) engineering accreditation program outcomes in 2000 , specifically outcomes (h) "the broad education necessary to understand the impact of engineering solutions in a global and societal context" and (j) "a knowledge of contemporary issues."
In addition, there are broader impacts of this project. These include providing curriculum attractive and meaningful to female students. More women graduated in 2003 with degrees in environmental engineering than any other engineering discipline (ASEE 2003; Beder 1989; Tietjen 2004). The project should help attract underrepresented minority groups to Kettering University on a similar basis. Kettering has many initiatives to attract and retain minority students. Industrial ecology coursework could be used, for example, in summer programs for minority high school students or as preparation for funded thesis projects.

Finally, the project should contribute to the human resource needs of industry and society at large as environmental quality becomes an increasingly important economic and social issue. Beyond offering an undergraduate course, the authors may use material from this project to deliver noncredit continuing education courses to practicing professionals.

The need for coursework in industrial ecology is clear from Kettering University's cooperative education employers. Historically, Kettering has deep roots in the manufacturing sector, especially among automotive firms. Concerns over the life cycle of automobiles and related legislation in the European Union (Kimberley 2004) are examples that demonstrate the importance of the topic. Kettering is also involved in research and curriculum development on fuel cell vehicles. Coursework in the fuel cell area is highly complementary to this project.

With these motivations in mind, a group of faculty representing all of Kettering University's academic departments formed the Kettering Industrial Ecology Team (KIET). This paper highlights the group's work to date and future plans. 


\section{Project Goals and Activities}

The primary goal of this project is the development of a multidisciplinary course in industrial ecology. KIET projects the course will first run in the winter of 2007 . This course will provide students with the perspective and skills (economic, managerial, ethical, scientific, and engineering) needed to critically examine environmental issues in product design and manufacturing and arrive at viable solutions to these problems. The course will be open to engineering, science, and management undergraduate and graduate students and will focus on the environmental aspects of the goods and services produced by Kettering University's industrial cooperative education partners.

A second goal of KIET is to incorporate input from relevant stakeholders, with a particular emphasis on Kettering University's industrial cooperative education partners in the automotive and furniture industries. KIET has already begun work with these industries and will continue to do so throughout the project's duration. First, the proposed course will adapt material and the teaching approach from the Ford Partnership for Advanced Studies (Ford PAS) curriculum, specifically the module titled "Closing the Environmental Loop." Second, KIET has assembled an advisory board of academic and industry experts to provide valuable input. This board has met twice as of this writing to provide guidance to the group.

A third goal of KIET is to integrate the course into the Kettering University curriculum and expand awareness and interest in the topic among Kettering students, faculty, and alumni. KIET will do this through the development and promotion of a formal course. The team has obtained approval for the course as part of the university's curriculum. In addition, KIET sponsors on-campus lectures for the general university community and off-campus tours for select student groups. KIET holds on-campus lectures each semester (four times per year) to large numbers of students (more than 50 per lecture). The group has measured student reaction by survey and found it to be strongly positive regarding the lecture material and the topic of industrial ecology in general.

A fourth goal is the implementation of an evaluation and assessment plan to measure the success of the project in accomplishing its stated goals and the success of the proposed course in achieving appropriate learning objectives. KIET will pursue continu- ous improvement in its efforts through the life of the project. The team has contracted a third party to formally assess the project.

A fifth goal of KIET is dissemination of materials and methods developed as a result of the project to engineering faculty at other schools. The team has authored this publication along with several conference papers to help achieve this goal and wants to be a positive force in enhancing the curricula of other institutions.

Most notably, KIET received NSF CCLI funding (DUE-0511322) to support its efforts to develop the course and disseminate results to other colleges and universities. Further, the team has approached a number of industry sponsors seeking funding and general support of the project. The group is continuing to seek additional funding sources to support an expanded scope for the project.

\section{Curriculum Design}

The KIET group, working with the advisory board, determined that a useful starting point for this project was the Ford PAS (Partnership for Advanced Studies) program. In particular, KIET believes that the PAS module, "Closing the Environmental Loop," is an exemplary prototype for adaptation. During the 1990s, a precursor curriculum to Ford PAS reached more than 70 high schools, had $40 \%$ female enrollment, and had significant minority representation. A follow-up survey found that $61 \%$ of these participants enrolled in post-secondary STEM (science, technology, engineering, and mathematics) disciplines (Poledink 2004). This suggests that the PAS curriculum will be equally effective in appealing to female and minority students in encouraging them to pursue bachelor's degrees in STEM fields. KIET is continuing to attend PAS events to become more familiar with this curriculum.

\section{Course Learning Objectives}

After thorough review of the literature and the Ford PAS curriculum, the team identified the following course learning objectives:

1. Understand the historical, social, legal, and ethical issues underlying the environmental impact of goods and services.

2. Evaluate life cycle analyses of products and/or processes and propose strategies for minimiz- 
ing environmental impact while still meeting design and economic requirements.

3. Conduct a material selection with the goal of reducing the environmental impact of a product and/or process while simultaneously reducing material costs.

4. Employ appropriate tools to evaluate the environmental impact of a manufacturing process and recommend actions to reduce both this impact and production costs.

5. Analyze and propose changes to a product design that result in enhanced recycling, reuse, and/or remanufacturing capabilities with consideration of the economics of these activities.

6. Identify the relative merits of various approaches to industrial ecology within a corporation.

7. Demonstrate enhanced critical thinking through exhibiting successful application of problemsolving strategies, high intellectual standards, and the traits of master reasoners.

\section{Course Modules}

KIET is developing six course modules to accomplish the objectives listed above. The team will use these modules in a 12-week course for senior-level undergraduate and graduate students. The material may be "repackaged" for use in continuing education courses. The modules (each lasting about two weeks) include:

1. Technology, the environment, and industrial ecology. In this module, students will be introduced to the broader historical, social, and ethical dimensions of industrial activity, paying particular attention to environmental impacts. Discussion of the need to move toward a sustainable society will be followed by introduction of the notion of industrial ecology and sustainable business practices. Students will also be introduced to basic environmental science and specific environmental performance metrics.

2. Life cycle concepts and assessment. This module presents students with the notion that environmental impact extends beyond production to include material extraction, product use, and end-of-use strategies. Students will discuss life cycle stages for a variety of example products. Strategies for assessing the impact of each life cycle stage will be presented, and the students will explore the advantages and challenges associated with each.

3. Material selection strategies and requirements. In this module, students will be introduced to environmental impact measures, industrial standards and guidelines, decision-making strategies that can be used for material selection, and computer tools.

4. Process design and improvement. Students will be introduced to methods of identifying the most damaging part of the process flow through material and energy balances. Common practices for reducing energy consumption and waste will be discussed. In addition, strategies for environmentally sustainable product packaging and delivery will be presented.

5. End-of-use strategies. This module addresses strategies and challenges associated with reducing the environmental impact of a product after it has been used by a consumer or business. Discussion will focus on reuse, remanufacturing, recycling, and disposal options. Design for recycling tools will be demonstrated and practiced on real products.

6. Environmentally responsible management. This module will present current best practices in promoting design for the environment within the corporation. In addition, the module will introduce students to current trends in environmental management systems, green supply chains, lean manufacturing, and total cost accounting. At this writing, team members have authored a draft of this module and are currently testing the material.

\section{Teaching Methodology}

KIET is designing the course to create a learning environment that incorporates knowledge, learner, and assessment-centered perspectives as described in the National Research Council report on connecting educational theory with educational practice entitled "How People Learn: Brain, Mind, Experience and School" (NRC 2000). To achieve this goal, the course will consist of a set of self-contained modules. Though the specific content will vary, each module will contain the following common elements: (1) a motivational case study, (2) learner-appropriate content knowledge (Barr 1995), (3) active learning strategies (Richards 1995), and (4) opportunities for formative and summative assessment (Frechtling et al. 2002). 
A modular design allows instructors to address each learning objective independently, simplifying assessment. In addition, modules can be resequenced from term to term depending on the availability of plant tours, guest speakers, and so on, and modified independently depending on assessment and evaluation results. Another potential benefit of a modular design is that modules can be more easily integrated into courses at Kettering University or other institutions, contributing to more effective dissemination. Further, KIET may offer some of the modules to nontraditional audiences, such as noncredit continuing education programs.

Each module will be introduced by a case study of an environmental problem in industry. Case studies have been shown to be highly effective means of motivating students to learn, increasing knowledge transfer (Bocker 1987), encouraging active learning (Kenney 2001) and introducing ambiguity into decision making (Banning 2003).

There already exists a rich body of case studies in the environmental areas. KIET will select cases from the existing body or develop new case studies during the first year of the proposed project. As an example, the Ford PAS project uses the life cycle of a tennis shoe to appeal to students. Cases on McDonald's hamburger wrappers (Svoboda 1995) are another example that students can easily identify with and that illustrate the trade-offs of environmental, financial, and public relations factors that organizations face in their operations.

\section{Evaluation and Dissemination}

The KIET project evaluation plan is directly aimed at the project objectives using both formative and summative evaluation methods. A mixed-methods approach, as described in the National Science Foundation report, "The 2002 User-Friendly Handbook for Project Evaluation" (Frechtling et al. 2002), will be employed at all levels of evaluation. The formative assessment data will flow into a continuous improvement process model outlined within the framework of this proposal. The first formative evaluation process will consist of surveying the individuals involved in the faculty development activities to assess their level of satisfaction and gather suggestions to achieve project goals. All KIET members will also be surveyed three times over the life of the project to elicit their input. Furthermore, advisory board members will be surveyed at least three times during this project to assess their level of satisfaction with meeting process, quality of the curriculum materials, and direction of the project. All of this information will be used to report to funding sources and to make mid-course corrections if necessary.

Once KIET begins to offer the course (projected for the winter of 2007), surveys will be used to gather faculty and student input for further refinement and to assess the degree to which the project objectives have been met. Examples of student work will be provided to the advisory board to assess whether the course is achieving its stated learning objectives. Focus groups of students enrolled in the course will also be used to measure their satisfaction with the course and the extent to which their attitudes toward the engineer's role in society has changed. Demographic information will be collected in every survey in the evaluation plan to assess the degree to which the diversity goals are being met.

The results of this project will be disseminated in several ways. First, KIET will disseminate the results of their work via a free course kit, which will contain a full set of multimedia teaching materials on a $C D$. This $C D$ will be distributed at workshops on campus and at professional conferences. KIET will also host an active Web site at Kettering University that includes the materials available on the CD kit. A link to the Kettering site will be available at $h t t p: / / w w w . m e r l o t . o r g, a$ Web site dedicated to sharing and providing evaluation of educational resources.

Second, the team will host a series of workshops at Kettering University and professional conferences (such as those of the American Society for Engineering Education, Society of Automotive Engineers, and American Chemical Society) or upon request at individual institutions. At these workshops, KIET will distribute the CD kits for free. Workshops will be designed as half-day sessions and will include information about the subject area and teaching aspects of industrial ecology.

Third, KIET team members will prepare conference papers and journal articles in subject area outlets as well as pedagogical outlets. The purpose of these papers and articles is twofold: to spread information about the project and to demonstrate that industrial ecology courses can be readily created using the materials provided in the $C D$ kit. 
Finally, KIET team members will report their findings to each of the project's funding sources through annual advisory board meetings and annual reports to the National Science Foundation. This reporting will include both the course material (on CD) and the results of the project evaluation.

As of this writing, KIET has begun evaluation activities. As noted above, at the end of each on-campus speaker activity, KIET surveys students regarding their attitudes toward the presentation and the field of industrial ecology. The group has discovered a strong level of student interest in industrial ecology. Further, KIET has received valuable feedback and strong support from its advisory board. Board members have coauthored papers with team members and given suggested areas for case studies and module topics. The industrial members have repeatedly underscored the importance of this topic in engineering education from their firms' perspectives. The team's external evaluator has also begun data collection.

\section{Future Plans}

At the time of this writing, KIET has received NSF funding for this proposal (DUE-0511322). The group has begun a three-year implementation cycle with activities noted above. During the first nine months of 2006, the group will focus on the following concurrent activities:

1. Curriculum development - Each of the six modules is being developed by a faculty team and prototyped by the entire KIET team.

2. Speaker series - Each semester (four times per year), KIET is sponsoring a lecture on campus regarding industrial ecology.

3. Student society - KIET is encouraging the formation of a student society to support industrial ecology efforts.

4. Outreach activities - KIET is exploring outreach activities with $\mathrm{K}-12$ educators in the Flint, MI, area.

5. Further funding - KIET is exploring additional funding sources for further activities.

KIET's efforts will reach a peak when the new multidisciplinary course in Industrial Ecology is first offered in the winter of 2007. At that time, further evaluation activities outlined above and a continuous improvement effort will begin. These activities will continue through 2008.

\section{Conclusion}

Rising environmental concerns have led to a need for new curricula in the area of industrial ecology. This project is a multidisciplinary effort to educate aspiring engineering students and prepare them to design sustainable products for the future. The effort is well under way and expanding in scope.

\section{References}

ASEE (American Society for Engineering Education) (2003). "Bachelor's degrees 2002-2003 awarded to women by discipline." ASEE Profiles of Engg. and Engg. Technology Colleges. Washington. DC: ASEE.

Banning. K.C. (2003). "The effect of the case method on tolerance for ambiguity." Journal of Mgmt. Education (v27, n5).

Beder, S. (1989). "Towards a more representative engineering education." Int'l Journal of Applied Engg. Education (v5, n2), pp173-182.

Bocker. F. (1987). "Is case teaching more effective than lecture teaching in business administration? An exploratory analysis." Interfaces (v17, n5), pp64-72.

Frechtling, J.; Frierson, H.; Hood, S.; and Hughes, G. (2002). The 2002 User Friendly Handbook for Project Evaluation. REC 99. 12175. Arlington, VA: National Science Foundation.

Kenney, S.J. (2001). "Using the master's tools to dismantle the master's house: can we harness the virtues of case teaching?" Journal of Policy Analysis and Mgint. (v20, n2).

Kimberley, W. (2004). "European vehicle manufacturers face recycling requirements." Automotive Design \& Production (v116, n8), pp20-22.

National Academy of Engineering (2004). The Engineer of 2020: Visions of Engineering in the New Century. Washington. DC: The National Academies Press.

National Research Council (2000). How People Learn: Brain. Mind. Experience and School. Washington. DC: The National Academies Press.

Poledink, P. (2004). Telephone interview with Paul Poledink, director of Ford PAS, Nov, 2004.

Powers. S.E.; Zander. K.; Theis, T.L.: and Maclean, H. (2002). "Incorporating industrial ecology and sustainability concepts into environmental engineering courses." AEESP/AAEE 2002 Education and Research Conf. Clarkson Center for the Environment.

Svoboda. S. (1995). "Case B1: the clamshell controversy." National Pollution Prevention Center for Higher Education. http:// css.snre.umich.edu.

Tietjen, J.S. (2004). "Why so few women, still?" Spectrum Online. http://www.spectrum.ieee.org/WEBONLY/resource/oct04/ 1004care.html.

\section{Authors' Biographies}

Andrew Borchers, DBA, serves as an associate professor of information systems at Kettering University (Flint. MI). Prior to entering full-time academic life, he spent 21 years working as an IT professional and manager for General Motors Corporation and Electronic Data Systems. His professional and academic interests are varied and include information technology, entrepreneurship, and environmental sustainability. He holds academic degrees from Kettering University, Vanderbilt University, and Nova Southeastem University. Borchers serves as associate editor of the Journal of Cases in Information Technology and is on the editorial board of Information Resources Management Journal.

Trevor Harding, $\mathrm{PhD}$, is an associate professor of industrial and manufacturing engineering at Kettering University, where he teaches 
courses in materials selection in design, introductory engineering materials, and manufacturing processes. His research interests include alternative bearing materials for orthopedic prosthetic devices, ethical decision making in engineering practice, and the development of curricula in the area of sustainable engineering practices.

Terri Lynch-Caris, PhD, PE, is an assistant professor of industrial and manufacturing engineering. She received her doctoral degree from the University of Michigan and master's degree from Purdue University. She is a licensed professional engineer in the state of Michigan and has industrial experience at Ford Motor Company and General Motors Corporation. Her areas of interest in teaching and research include ergonomics, statistics, work design. human modeling, and industrial ecology. She serves as the faculty advisor for the Institute of Industrial Engineers (IIE) student chapter at Kettering University and is an officer of the Industrial Engineering Division of the American Society of Engineering Education (ASEE).

Benjamin Redekop is associate professor of social science and Francis Willson Thompson chair of Leadership Studies in the Dept. of Liberal Studies at Kettering University. He has published books and articles in European Intellectual History, the History of Science, and Anabaptist/Mennonite History and Thought. He teaches courses at
Kettering in the humanities and social sciences. Redekop is currently at work on a book chronicling the rise and spread of common sense philosophy, and a book profiling the views of industry leaders on the relationship between leadership and ethics.

Craig J. Hoff, PhD. PE, is a professor of mechanical engineering at Kettering University (Flint, MI). He teaches in the areas of energy systems, mechanical design. and automotive engineering. His research is focused on alternative automotive power trains, including fuel cell and hybrid electric vehicles. He earned his $\mathrm{PhD}$ in mechanical engineering from the University of Michigan and is a licensed professional engineer in the state of Michigan.

Jackie El-Sayed, $\mathrm{PhD}$, is an associate professor at her alma mater, Kettering University, where she teaches courses in mechanical engineering. Dr. El-Sayed's research is in the area of manufacturing optimization and involves the use of multiobjective, nonlinear optimization techniques as well as formability simulation of automotive body structural sections in the early design stage of vehicle development process. She currently is the director of the Center for Excellence in Teaching and Learning at Kettering and also the chair of the Michigan Truck Safety Commission, appointed by Michigan's governor. 